\title{
SIKAP MUSLIM SEBAGAI MINORITAS: ANALISIS WACANA PESAN DAKWAH FILM AYAT- AYAT CINTA 2
}

\author{
Eko Agoes Setiawan \\ STID Al-Hadid, Surabaya \\ eko.agoes92@gmail.com
}

\begin{abstract}
Abstrak: Dakwah memerlukan media penyampaian, salah satunya adalah film. Film memiliki kemampuan untuk memengaruhi penonton sesuai pesan dakwah yang diinginkan. Salah satu pesan dakwah yang diangkat adalah kehidupan kaum muslim minoritas. Isu mengenai kehidupan muslim di Eropa yang menunjukkan posisi muslim sebagai minoritas menarik untuk diulas. Faktanya tidak sedikit kaum muslim minoritas yang keliru dalam bersikap di tengah lingkungan nonmuslim. Film AyatAyat Cinta 2 salah satunya menampilkan wacana cerita kehidupan kaum muslim sebagai minoritas. Tulisan ini hendak menganalisis wacana pesan dakwah kehidupan kaum muslim minoritas yang ditampilkan dalam adegan dan dialog film. Proses pengambilan data dilakukan pada adegan film yang menggambarkan bagaimana kehidupan kaum muslim dalam lingkungan yang minoritas. Studi menggunakan riset kualitatif, untuk analisis wacana menggunakan pendekatan Roger Fowler, dkk. Kesimpulannya wacana pesan dakwah yang ditampilkan adalah muslim sekalipun minoritas harus mau membantu tetangganya tanpa melihat identitas agamanya, kaum muslim bisa memberikan maaf jika ada tindakan lingkungan yang merugikan, tetangga dianggap sebagai keluarga, dan menjauhi suatu kaum tidak didasarkan kepada identitas agama melainkan karena sikap merugikan yang dimunculkan.
\end{abstract}

Kata Kunci: Sikap muslim sebagai minoritas, analisis wacana pesan dakwah, AyatAyat Cinta 2

Attitude of Moslem As A Religious Minority: Discourse Analysis of Da'wah Message in The Movie of Ayat-Ayat Cinta 2. Abstract: Da'wah / propagation requires media of delivery, one of them is a movie. A movie has an ability for influencing audience with the da'wah message intended. One of the da'wah messages promoted is the life of moslem as a religious minority. Issues related to moslem's life in Europe showing moslem as a religious minority are interesting to cover. In actual fact, there are moslems who act inappropriately in the middle of nonmoslem's life. Ayat-Ayat Cinta 2 is one of the movies which shows the life of moslem as a religious minority. This paper intends to analyze the discourse of da'wah messages in the lives of moslem as a religious minority shown in the scenes and dialogues. Data collection was conducted in the movie scenes which showed on how the life of moslems in their environment as minority. It based on qualitative research and uses Roger Fowler, et. al as the analysis approach. In conclusion, the discourses of da'wah message shown are Moslems, as a religious minority, should be willing to help their neighbors without seeing religious identities, Moslems can apologize if there are harmful attitudes from the surroundings, the neighbors should be considered as relatives, and staying a community away based on the harms they can emerge and not based on their religious identities.

Keywords: Moslem's attitude as a religious minority, discourse analysis for da'wah message, Ayat-Ayat Cinta 2 


\section{Pendahuluan}

Kesuksesan dakwah dapat dicapai salah satunya dengan memperhatikan media penyampaiannya. Media penyampaian dapat diibaratkan sebuah selang yang menghubungkan dari sumber air kepada tempat penampungan yang diharapkan. Media dapat dibagi menjadi tiga macam yakni pertama, media terucap yaitu media dakwah yang berupa ucapan atau bunyi yang dapat ditangkap indra telinga seperti radio dan telepon. Kedua, media tertulis yaitu media berupa tulisan atau cetakan seperti majalah, surat kabar, buku, pamflet, lukisan, gambar dan sejenisnya yang dapat ditangkap dengan indra mata. Ketiga, media dengar pandang (audiovisual) yaitu media dakwah yang berbentuk gambar hidup yang bisa dilihat dan didengar yaitu video, televisi, film. ${ }^{1}$ Film sebagai media dakwah yang bersifat audiovisual memiliki beberapa keunikan dan kelebihan seperti: (a) secara psikologis, penyajian di dalam film terasa lebih nyata dan mudah, hal ini membantu pesan dakwah yang mungkin akan sulit dipahami jika dijelaskan dengan kata-kata; (b) secara kelekatan, media film lebih mudah diingat dan bisa membuat orang yang menonton tidak lupa dengan hal yang disampaikan atau disajikan dalam film. ${ }^{2}$ Dua hal ini membuat film menjadi alternatif dalam menyampaikan pesan dakwah kepada masyarakat.

Media dan wacana tidak bisa dipisahkan, Ismail Marahimin menjelaskan wacana sebagai kemampuan untuk maju (dalam pembahasan) menurut urutan yang teratur dan semestinya dan komunikasi buah

\footnotetext{
${ }^{1}$ Moh. Ali Aziz, Ilmu Dakwah, (Jakarta: Kencana, 2009), 149.

2 Ibid., 426.
}

pikiran, baik lisan maupun tulisan. Terdapat dua unsur penting dalam sebuah wacana yakni kesatuan dan kepaduan. ${ }^{3}$ Penjelasan tersebut memberikan arti bahwa wacana adalah studi mengenai bahasa atau pemakaian bahasa dalam sebuah komunikasi yang bersifat berurutan atau logis. Di sisi lain, media sebagai sarana informasi masyarakat memiliki kemampuan untuk membentuk dan mengarahkan opini publik karena media bukanlah pihak yang bebas, independen, melainkan sangat erat hubungannya dengan kepentingan. Kepentingan ini bisa berasal dari kelompok dominan atau berkuasa yang ingin mempertahankan eksistensinya. Salah satu kepentingan media adalah kapitalisme pemilik modal. Kepentingan tersebut akan membawa dampak apa-apa yang akan disampaikan oleh media akan mengarahkan kepada kapitalisme pemilik modal. ${ }^{4}$ Dalam praktiknya tecermin dari wacana-wacana yang disampaikan pihak-pihak tertentu dalam rangka mencapai kepentingannya termasuk dalam sebuah film yang bertemakan agama, termasuk dalam media film.

Kehidupan yang berkaitan dengan kaum muslim menjadi salah satu pilihan tema dalam sebuah film yang bisa diambil. Salah satu perhatian adalah bagaimana kehidupan umat muslim di negara-negara yang secara sosial budaya maupun politik tidak berdasarkan ajaran Islam. Realitas ini muncul dalam beberapa penelitian mengenai bagaimana kehidupan umat muslim di Barat, salah satunya di Eropa. Di Inggris, menurut catatan pihak kepolisian

\footnotetext{
3 Alex Sobur, Analisis Teks Media: Suatu Pengantar untuk Analisis Wacana, Analisis Semiotik, dan Analisis Framing (Bandung: Remaja Rosdakarya, 2009), 10. 4 Ibid., 30.
} 
Inggris, terjadi peningkatan kasus kejahatan yang didasarkan pada agama. Terjadi kenaikan hampir 40\% kasus dari 2016-2017 ke 2017-2018, dan 52\% kejahatan yang berdasarkan kebencian diarahkan kepada umat Islam. Kejahatan ini mencakup cacian, intimidasi, ancaman, pelecehan, penyerangan dan perusakan properti. ${ }^{5}$ Kejadian lainnya berasal dari tindakan pihak atau kelompok yang tidak bertanggungjawab dan mengatasnamakan Islam seperti kelompok teroris. Akibat adanya kelompok tersebut, umat Islam mendapat stigma negatif. Salah satu contohnya, kasus yang dialami oleh salah seorang warga muslim di Inggris yang benama Usman Ahmed, yang mengalami sasaran kebencian dengan menyebutnya sebagai anggota Negara Islam atau ISIS. ${ }^{6}$ Menurut Wakil Menteri Luar Negeri Amerika Serikat untuk Demokrasi, HAM, dan Buruh, Michael Posner, juga mengatakan bahwa dirinya masih melihat diskriminasi dan kebencian terhadap umat Islam di Eropa. ${ }^{7}$ Dampak yang timbul adalah citra Islam sendiri dipandang negatif.

Citra negatif pada umat Islam dapat pula berasal dari perilaku oknum muslim. Salah satu hal yang bisa diperhatikan adalah seperti perilaku oknum sebagian muslim yang mudah sekali melabeli bahwa kelompok atau kalangan yang memiliki perbedaan dalam keyakinan merupakan kalangan kafir. ${ }^{8}$ Sikap ini akan memengaruhi

\footnotetext{
${ }^{5}$ BBC, "Lebih dari Setengah Kejahatan Kebencian di Inggris Menyasar Umat Muslim" bbc.com, diakses 9 Januari 2019, http://www.bbc.com/indonesia/dunia445884930

${ }^{6}$ Ibid.

${ }^{7}$ Republika.co.id, "Inilah Wajah Islam dalam Survei di Dunia Barat" republika.co.id, diakses 9 Januari 2019, http://n.republika.co.id/berita/dunia-Islam/Islammancanegara/10/07/09/123929-inilah-wajah-Islamdalam-survei-di-dunia-barat
}

interaksi dengan nonmuslim yang perlu untuk dijauhi sehingga membuat interaksi umat muslim menjadi hanya sekadar dari kelompoknya sendiri, sebagian umat muslim dengan pemikiran tersebut memilih untuk menjauh dari kalangan nonmuslim, sampai muncul sikap untuk membuat perumahan khusus orang muslim saja dimana kaum nonmuslim ditolak ketika hendak bertempat tinggal di daerah tersebut. ${ }^{9} \mathrm{Hal}$ ini bisa memunculkan citra negatif kepada kalangan umat muslim dan juga merusak ajaran Islam yang rahmatan lil alamin. Citra negatif bisa berdampak pada kehidupan masyarakat muslim, mulai dari interaksi secara sosial bahkan mungkin sampai aspek pekerjaan. Kalangan muslim yang hidup dalam kondisi mayoritas mungkin akan memiliki perbedaan dalam keadaan hidupnya. Kondisi ini tentu akan menarik untuk disajikan dalam sebuah film yang menceritakan bagaimana kehidupan umat Islam dalam negara yang mayoritas nonmuslim. Dengan kata lain muslim sebagai kalangan minoritas. Isu mengenai kaum minoritas adalah salah satu hal yang menjadi perhatian dunia. Beberapa permasalahan mengenai pelanggaran HAM ataupun intimidasi baik yang bersifat fisik maupun nonfisik kadang menjadi dan kerap kali dialami oleh golongan minoritas dalam suatu masyarakat, tidak terkecuali kaum muslim.

Film Ayat-Ayat Cinta 2 (AAC 2) merupakan film yang tayang pada 2017. Film ini

\footnotetext{
8 Utami Diah Kusumawati, "Muhammadiyah Imbau Umat Muslim Tak Obral Ucapan 'Kafir'” CNN Indonesia, diakses 2 Mei 2019, http://www.cnnindonesia.com/nasional/2015080811 2900-20-70816/muhammadiyah-imbau-umatmuslim-tak-obral-ucapan-kafir

9 Irwan Syambudi, "Perumahan Khusus Muslim dan Ancaman Toleransi di Yogyakarta" Tirto.id, diakses 2 Mei 2019, http://www.tirto.id/perumahan-khususmuslim-dan-ancaman-toleransi-di-yogyakarta-dl1D
} 
merupakan lanjutan dari film pertama yang berjudul sama dan cukup fenomenal di masyarakat dengan pencapaian penonton sebesar 3,5 juta penonton. ${ }^{10}$ Jumlah penonton film kedua bisa dibilang berada di bawah film pertamanya, namun secara angka masih cukup besar yakni 2,8 juta. ${ }^{11}$ Film tersebut diadaptasi dari novel karya Habiburrahman El Shirazy. Latar film pertama dan kedua memiliki kesamaan yakni berada di luar negeri, yang menjadi berbeda adalah AAC 2 mengambil lokasi di Skotlandia, dimana umat muslim merupakan kaum minoritas. Kehidupan muslim sebagai kaum minoritas di Eropa sebenarnya bisa dibilang cukup menarik karena dengan mayoritas kehidupan sosial budaya yang bukan berasal muslim, tuntutan untuk hidup dengan tetap mempertahankan nilai-nilai keislaman menjadi tantangan tersendiri.

Salah satu isu terkait masalah minoritas di Eropa adalah bagaimana sikap kalangan mayoritas yang merupakan nonmuslim melihat dan memiliki pandangan terhadap kaum muslim sebagai kelompok minoritas dalam masyarakatnya. Seperti yang sudah disinggung di atas, beberapa kejadian menimpa kalangan muslim di wilayah Eropa karena adanya sebuah stigma yang dilekatkan oleh masyarakat terhadap kaum muslim, kondisi ini memang bisa dipicu oleh beberapa tindakan yang bersifat teror di masyarakat Eropa dimana oknum yang melakukan teror tersebut adalah orang yang beragama Islam. Perilaku oknum ini mengakibatkan Islam mendapat citra negatif. Seorang muslim yang tidak memiliki niat buruk ataupun perilaku buruk disikapi negatif sebagai dampak stigma tersebut.

10 Ananda Putri, "Gairah di Industri Perfilman Nasional", SWA (Maret 2018): 27.
Berdasarkan sinopsis film AAC 2, inti cerita berfokus kepada tokoh utama yang bernama Fahri, sebagai sosok yang sekarang hidup di Skotlandia. Film ini menceritakan bagaimana kehidupan Fahri setelah istrinya, Aisha, yang menghilang dan tidak ada kabar ketika berkunjung ke Palestina, ditambah dengan kehidupan keseharian Fahri sebagai dosen di salah satu universitas. Kehidupan sosial Fahri juga cukup unik. Dia hidup di sebuah lingkungan yang secara agama digambarkan memiliki keragaman. Film tersebut bisa menunjukkan bagaimana sikap muslim terhadap lingkungan yang bukan sesama muslim, sekaligus bisa menjadikan media ini sebagai jalan untuk memperbaiki citra Islam.

Beberapa realitas yang menunjukkan adanya pesan dakwah dalam film adalah bagaimana sikap yang ditampilkan Fahri kepada tetangga-tetangganya, yang sekalipun nonmuslim, Fahri dengan senang hati menolong tetangganya yang membutuhkan. Ketika ada tetangganya yang nonmuslim menghina Fahri secara personal karena agama yang dipeluknya, Fahri tidak lantas berbalik menghinanya, karena memahami bahwa tetangganya yang menghina masih belum mengenal Islam. Malah Fahri mendoakannya. Sikap-sikap yang ditampilkan tokoh Fahri dalam film tersebut menunjukkan adanya pesan dakwah terkait sikap seorang muslim dalam kehidupan sosial, khususnya ketika la tinggal di lingkungan mayoritas nonmuslim. Wacana dalam film AAC 2 dapat dianalisis dalam berbagai aspek. Dalam studi ini dilakukan analisis wacana dalam aspek pesan dakwahnya terkait sikap muslim sebagai kaum minoritas. Salah satu pendekatan dakwah adalah dakwah bil hal, atau dakwah

11 lbid., 27. 
dengan perbuatan. Sikap yang ditampilkan oleh Fahri dalam film AAC 2 sebagai sosok muslim yang hidup di lingkungan nonmuslim adalah bentuk dakwah bil hal. Oleh karenanya diasumsikan mengandung muatan-muatan pesan dakwah yang dapat digali lebih lanjut melalui analisis wacana film.

Fokus masalah dalam studi ini adalah bagaimana analisis wacana pesan dakwah dalam film AAC 2 terkait sikap muslim sebagai minoritas. Tujuan studi adalah mendeskripsikan wacana pesan dakwah sikap muslim sebagai minoritas dalam film $A A C$ 2. Berdasarkan tinjauan pustaka, didapatkan beberapa studi yang membahas mengenai AAC 2, studi tentang peran film AAC 2 terhadap perilaku etika Islam pada remaja, studi ini memfokuskan pengaruh film terhadap perilaku remaja di salah satu SMP di Bandung dengan cara melakukan pengambilan sampel kepada siswa-siswa yang sudah menonton saja. Hasil studi menunjukkan bahwa film memiliki pengaruh terhadap etika Islam. $^{12}$ Berikutnya studi tentang analisis wacana pesan toleransi antar umat beragama dalam novel AAC 2 karya Habiburrahman El Shirazy, studi ini fokus untuk menganalisis wacana teks dengan wacana Teun A. Van Dijk. Hasil studi ini menjelaskan bahwa menghargai cara beribadah umat yahudi, berbaik sangka pada orang islamofobia dan memberi nasihat untuk bersikap toleran dan bersatu di tengah perbedaan agama yang ada dalam misi kemanusiaan, dimana wacana toleransi dipengaruhi oleh latar belakang akademis dan nonakademis penulis serta kondisi sosial

12 Muhammad Wahyuda, "Peran film Ayat Ayat Cinta 2 Terhadap Perilaku Etika Islam Pada Remaja," Syifa AlQulub Vol. 2, no. 2 (2018): 31. masyarakat muslim di Eropa yang sering kali didiskriminasi dan dicap buruk. ${ }^{13}$ Perbedaan dengan studi sebelumnya adalah studi ini menggunakan film dan menganalisis mengenai pesan dakwah yang ada di dalam film mengenai sikap muslim dalam kondisi minoritas. Film merupakan realitas penyajian yang sangat berbeda dengan novel, dimana novel mampu menjelaskan keseluruhan kondisi kedirian maupun situasi sehingga pembaca bisa memiliki tafsiran mengenai kondisi tersebut, namun dalam film hal itu tidak terlalu tampak karena sudah digambarkan dengan setting yang digunakan, penonton tentu sudah disuguhi dengan gambaran yang ditentukan oleh pembuat film. Dalam beberapa kasus film yang mengambil dari novel, isi film terkadang ada semacam improvisasi dari novelnya sehingga dimungkinkan adanya perubahan walaupun tidak berbeda jauh dengan inti ceritanya. Penyajian berupa film merupakan karya yang juga bisa diuji secara terpisah terlepas ada tidaknya novel yang menjadi dasar ceritanya.

Studi dalam tulisan ini menggunakan pendekatan kualitatif deskriptif, dengan berpijak pada metode analisis wacana Roger Fowler dkk. Dalam pengumpulan data menggunakan teknik dokumentasi video film Ayat-Ayat Cinta 2. Video film berasal dari aplikasi streaming "Hooq", dari video tersebut ditranskripkan menjadi teks yang kemudian akan menjadi bahan untuk analisis wacana dalam film. Metode analisis data berdasarkan Miles dan Huberman terdiri dari tiga tahap yakni data reduction, data display, dan conclusion

\footnotetext{
${ }^{13}$ Ricca Junia Ilprima, “Analisis Wacana Pesan Toleransi Antarumat Beragama Dalam Novel Ayat-Ayat Cinta 2 karya Habiburrahman El Shirazy" (Skripsi, UIN Syarif Hiyatullah Jakarta, 2016), i.
} 
drawing/verification. ${ }^{14}$ Reduksi data dalam film menyampaikan tentang realitas dan alur yang berkaitan dengan realitas kehidupan seorang muslim yang diwakilkan oleh sosok Fahri. Penyajian data dalam film akan disajikan dalam bentuk transkrip dialog setiap adegan, situasi, kemudian status kondisi yang dipandang mewakili cerminan bagaimana kehidupan muslim dalam negara yang mayoritas bukan muslim. Sedangkan untuk kesimpulannya murni berdasarkan konteks dalam film Ayat-Ayat Cinta 2 saja. Tidak menjadi cerminan dari kehidupan muslim di negara-negara tersebut. Dalam tulisan ini, akan dijelaskan alur cerita dari film Ayat-Ayat Cinta 2 yang kemudian akan dianalisis alur cerita tersebut dengan analisis wacana Roger Fowler dkk. Sebelumnya akan diuraikan pijakan teoretis yang digunakan, yaitu terkait pesan dakwah dalam film, konsepsi sikap muslim terhadap nonmuslim, dan analisis wacana Roger Fowler, dkk.

\section{Pesan Dakwah dalam Film}

Pesan dakwah adalah isi atau materi (maddah) yang disampaikan dai kepada mitra dakwah. Secara umum meliputi akidah, syariat meliputi ibadah dan muamalah, dan akhlak. Sumbernya dari Alquran, hadis, atsar sahabat, pendapat atau fatwa ulama, ilmu pengetahuan, dan lainlain. Media dakwah adalah alat yang dipergunakan untuk menyampaikan materi dakwah kepada mitra dakwah. Secara umum ada lima macam media yaitu lisan, tulisan, lukisan, audio visual dan akhlak/perbuatan. ${ }^{15}$ Pesan akidah adalah suatu pesan yang berisikan tentang sistem keimanan kepada Allah Swt. yang terkait dengan iman kepada

\footnotetext{
14 Sugiyono, Metode Penelitian Kuantitatif Kualitatif dan R\&D (Bandung: Alfabeta, 2012), 246.

${ }^{15}$ Aziz, IImu Dakwah., 75, 92 - 94, 120 - 124.
}

Allah, kepada malaikat, kitab rasul, qadla dan qadar serta hari akhir atau kiamat. Pesan syariat adalah suatu pesan yang berkaitan dengan tuntunan atau ajaran Islam yang berisikan tentang tata cara beribadah. Berkaitan dengan hal-hal yang boleh dan tidak boleh, yang dilarang, dianjurkan atau dibolehkan. Pesan muamalah adalah suatu pesan yang berisikan mengenai sistem interaksi dan hubungan antar manusia baik secara individu maupun kelompok. Pesan akhlak adalah pesan yang berkaitan dengan tata cara menghias diri dalam melakukan hubungan dengan Allah (ibadah) dan berhubungan dengan sesama manusia dan sesama makhluk yang menyangkut baik buruk, pantas dan tidak pantas, sampai berkaitan dengan rasa terhadap sesama. ${ }^{16}$

Film merupakan salah satu media dakwah yang bisa digunakan. Film sebagai media dakwah dapat berfungsi untuk mengajak orang dalam amar makruf nahi mungkar. Kekuatan dan kemampuan film dalam menjangkau kalangan masyarakat berpotensi mampu memengaruhi sikap ataupun perilaku penontonnya. Dari sisi kelebihannya yang tidak dimiliki oleh media lain, film bersifat audiovisual. Beberapa keunikan film sebagai media dakwah adalah film mampu menyuguhkan pesan yang hidup dan bisa mengurangi keraguan akan yang disampaikan, lebih mudah diingat. Secara psikologis, penyuguhan yang hidup mampu memberikan efek bahwa hal-hal yang sama, abstrak atau samar dapat diterangkan dengan film sehingga pesan yang disampaikan kepada masyarakat lebih baik dan efisien. Dalam konteks dakwah,

16 Ropingi el Ishaq, Pengantar Ilmu Dakwah; Studi Komprehensif Dakwah dari Teori ke Praktik (Malang: Madani, 2016), 77-80. 
sutradara pun bisa dianggap sebagai dai, karena ia menyambung pemikiran sang tokoh untuk ditonton, dengan harapan menjadi panutan masyarakat dalam mengaktuskan nilai-nilai agama dalam kehidupannya. ${ }^{17}$ Di masyarakat, film dapat mengubah pola hidup masyarakat, alasannya karena masyarakat ingin mencontoh kehidupan yang dikisahkan dalam film, terlebih jika tokoh yang memerankan adalah idolanya. Dengan demikian film jika dikaitkan dengan aktivitas dakwah, film dapat digunakan sebagai media informasi dengan demikian dai akan dapat lebih banyak menginformasikan hal-hal positif tentang Islam meliputi aspek akidah, syariat, maupun akhlak. Jika dilihat dari fungsinya, maka film sebagai media dakwah memiliki beberapa fungsi yakni: (a) untuk menginformasikan sesuatu kepada pihak lain; (b) untuk memberikan pengetahuan, nilai-nilai maupun hal-hal terkait yang bertujuan mencerdaskan penerima film; (c) untuk memengaruhi aspek kognisi (pemahaman), afeksi (sikap), maupun psikomotor (perilaku); (d) untuk memberikan hiburan sehingga kegiatan dakwah tidak monoton. ${ }^{18}$

\section{Sikap Muslim terhadap Kaum Nonmuslim}

Dalam konteks muslim sebagai minoritas di sebuah masyarakat, maka otomatis akan berhadapan dengan nonmuslim. Ada beberapa pandangan terkait hubungan interaksi sosial antara kaum muslim dengan

17 M. Ali Musyafak, "Film Religi Sebagai Media Dakwah Islam," Jurnal Islamic Review Vol. II, no.2 (2013): 335336.

18 Mubasyaroh, "Film Sebagai Media Dakwah (Sebuah Tawaran Alternatif Media Dakwah Kontemporer)," AtTabsyir Vol. 2, no. 2 (2014): 12-13. nonmuslim. Menurut pendapat M. Quraish Shihab dalam Tafsir Al-Misbah, menyatakan bahwa hubungan antara muslim dengan nonmuslim yang berkaitan dengan interaksi sosial diperbolehkan selama tidak membawa dampak negatif bagi umat Islam. Sedangkan menurut Hamka dalam Tafsir Al-Azhar, menjelaskan bahwa Allah tidak melarang umat muslim untuk berbuat baik, bergaul dengan baik, berlaku adil dan jujur dengan golongan lain, baik mereka yahudi, nasrani, ataupun musyrik selama mereka tidak memerangi, memusuhi dan mengusir umat muslim dari lingkungan tersebut. Menurut Imam Ar-Razi berpendapat bahwa yang tidak diperbolehkan dalam berinteraksi sosial dengan nonmuslim adalah jika umat muslim memaksa nonmuslim untuk mengikuti ajaran agama Islam. Menurut Ahmad Mushthafa dalam Tarsir Al-Maraghi dan Aidh Qarny dalam Tafsir Muyassar, beliau berpandangan bahwa Allah tidak melarang berbuat baik kepada orang kafir yang tidak memerangi kamu karena agama, tidak mengusir dari kampung halaman, yang dilarang adalah jika umat muslim bersahabat dengan orang-orang yang mengadakan permusuhan dengan umat muslim, sehingga bisa memerangi dan mengusir umat muslim. ${ }^{19}$ Dari penjelasan tersebut terdapat kesatuan pemahaman akan sikap muslim terhadap nonmuslim yakni diperbolehkan jika berkaitan dengan aspek interaksi sosial selama memang kalangan nonmuslim tidak melakukan tindakan yang berusaha untuk menghalangi sampai mengusir kalangan muslim dalam lingkungannya. Aspek yang tidak kalah penting adalah bahwa umat

19 Dirun, "Hubungan Muslim Non-Muslim dalam Interaksi Sosial (Studi Analisis Penafsiran Thabathabai dalam Kitab Tafsir al-mizan)" (Skripsi, UIN Walisongo Semarang, 2015), 43-47. 
muslim tidak diperbolehkan memaksa nonmuslim mengikuti ajaran Islam.

\section{Analisis Wacana Roger Fowler dkk.}

Konsep wacana yang dijelaskan oleh Roger Fowler dkk. berfokus pada struktur bahasa yang digunakan dalam menyampaikan sebuah informasi. Bahasa yang digunakan akan menunjukkan ideologi atau kepentingan apa yang dibawa dan ingin disampaikan kepada khalayak. Hal pertama yang dilihat dari bahasa adalah mengenai kosakata. Menurut Roger Fowler dkk. bahasa dilihat sebagai sebuah sistem klasifikasi, dimana membuat sebuah realitas memiliki gambaran yang berbeda ketika disampaikan, sampai pada aspek mengontrol bagaimana cara pandang seseorang atau khalayak terhadap sesuatu dengan bahasa tersebut. Contoh penggunaan bahasa yang berbeda menghasilkan sebuah klasifikasi yang berbeda mengenai suatu realitas adalah penggunaan kosakata mengenai adanya kegiatan dari negara lain kepada kejadian di dalam negeri, ada pemberitaan yang menggunakan kosakata intervensi dan ada juga yang menggunakan kosakata bantuan kemanusiaan. Dua kosakata tersebut memiliki makna dan gambaran realitas yang berbeda ketika disampaikan kepada khalayak.

Menurut Roger Fowler dkk. bahasa juga bisa bersifat membatasi pandangan, maksudnya adalah bahwa dasar bahasa adalah membatasi, yakni khalayak diajak untuk memahami seperti hal tertentu dan bukan yang lain. Sehingga dengan menggunakan kosakata tertentu maka akan memengaruhi cara pandang khalayak kepada suatu realitas atau peristiwa. Hal ini karena khalayak tidak mengikuti atau mengikuti suatu peristiwa secara langsung. Contoh penggunaan bahasa yang mampu membatasi pandangan adalah ketika ada peristiwa mengenai adanya pihak tertentu yang menyerang pihak tertentu. Dalam pemberitaan ada yang menggunakan istilah yang spesifik seperti pembunuhan, perang, dan lain sebagainya. Namun ada juga yang menggunakan istilah tragedi, insiden, kasus, dan lain sebagainya. kosakata tersebut jika disampaikan akan memengaruhi pandangan khalayak terhadap realitas tersebut.

Roger Fowler dkk. memaparkan bahwa bahasa juga bisa merupakan sebuah konteks pertarungan wacana dari berbagai pihak. $\mathrm{Hal}$ ini muncul atas dasar bahwa setiap pihak yang memiliki kepentingan untuk menunjukkan realitas tersebut kepada khalayak akan berusaha memberikan klaim kebenaran, dasar penjelas atau penjelas suatu masalah. Tujuannya tidak lain adalah untuk membuat versi yang dikeluarkan oleh pihak-pihak tersebut memiliki pengaruh kepada khalayak dan berakibat khalayak memiliki pandangan yang sama dengan apa yang disampaikan. Contoh penggunaan bahasa yang merupakan sebuah pertarungan wacana adalah adanya pemberitaan mengenai dua pihak yang berselisih. Media memberikan sudut pandang tentang perselisihan tersebut berdasarkan salah satu pihak atau kedua belah pihak. Semakin banyak media yang menonjolkan dari salah satu pihak maka kecenderungan khalayak akan menerima realitas atau peristiwa tersebut berdasarkan salah satu pihak dan itu merupakan sebuah 
kemenangan dalam pertarungan wacana kepada khalayak. $^{20}$

Menurut Roger Fowler dkk. bahasa juga merupakan sebuah upaya untuk memarginalkan suatu kelompok tertentu. Hal tersebut berhubungan dengan pertarungan wacana, dimana setiap pihak ingin menunjukkan bahwa dirinya yang benar. Setidaknya itu muncul dalam persepsi dan pemahaman khalayak, sehingga secara otomatis akan membuat pihak lainnya diposisikan sebagai pihak yang bersalah. Hal ini karena penggunaan kata tidak hanya dipahami sebagai struktur bahasa semata, melainkan dimunculkan dengan maksud untuk memengaruhi khalayak.

Selain memandang bahasa sebagai suatu kosakata yang tidak bebas namun memiliki kepentingan tertentu, Roger Fowler dkk. memandang bahwa bahasa merupakan sebuah paket antara kategori dan proses. Kategori yang penting disebut sebagai "model" yang menghubungkan antara objek dengan peristiwa yang terjadi. Ada tiga proses yang diperkenalkan Roger Fowler dkk. yaitu: pertama, model transitif, yang berhubungan dengan proses yang menunjukkan mana yang dianggap sebagai penyebab suatu tindakan dan bagian lain sebagai akibat dari suatu tindakan. Transitif ditandai dengan penggunaan kata kerja dalam suatu proses yang dilakukan oleh actor, contoh: "Pihak $\mathrm{X}$ memukul pihak $\mathrm{Y}$ ", dengan penggunaan tersebut maka digambarkan bahwa pihak $\mathrm{X}$ yang menjadi aktor dan menyebabkan sesuatu yang ditandai dengan adanya kata kerja. Kedua, model instransitif, menjelaskan mengenai suatu proses tanpa menghubungkan akibat

20 Eriyanto, Analisis Wacana (Yogyakarta: LkiS Yogyakarta, 2006), 134-149. atau objek yang dikenai, contohnya adalah "Pihak X berlari." Dari contoh tersebut tidak jelas mengapa dan untuk apa pihak $\mathrm{X}$ berlari. Ketiga, model relasional. Jika model pertama dan kedua berhubungan dengan tindakan, dimana ada pihak satu yang digambarkan menjadi pihak yang melakukan dan pihak lain sebagai pihak yang menerima tindakan tersebut. Model ketiga ini menghubungkan antara bagian tersebut. Hubungan ini bisa bersifat ekuatif dan atributif. Ekuatif berarti hubungan antara sama-sama kata benda, contohnya adalah kalimat "Korban tersebut adalah seorang ayah dari satu anak." Hubungan bersifat atributif berarti kata benda dihubungkan dengan kata sifat yang menujukkan kualitas atau penilaian tertentu, contohnya adalah kalimat "Orang itu sangat garang". ${ }^{21}$

Dari penjelasan tersebut diperoleh sebuah kerangka analisis dari Roger Fowler dkk. adalah berkaitan dengan penggunaan kata dan susunan kata atau kalimat. Kata yang digunakan bisa menunjukkan bagaimana peristiwa dan aktor yang ada dalam peristiwa tersebut dibahasakan atau ditampilkan. Kata yang dimunculkan tidak bersifat hanya sebagai penanda, melainkan kata ini memiliki kepentingan untuk dikomunikasikan kepada khalayak berdasarkan ideologi atau kepentingan tertentu, dimana dengan penggunaan kata itu akan diketahui pihak mana yang diuntungkan dan yang dirugikan posisinya. Susunan kalimat sendiri dipandang bukan hanya sekadar kebahasaan, melainkan susunan kalimat tersebut tetap dipandang bisa menimbulkan efek tertentu ketika disampaikan, dengan membuat salah satu pihak terlihat atau merasa lebih positif

21 lbid., 152. 
dibandingkan dengan pihak lain atau bisa juga menunjukkan sudut pandang tertentu yang lebih menguntungkan dari pada dengan sudut pandang lainnya. ${ }^{22}$

Tabel 1 - Kerangka Analisis Wacana Roger Fowler, dkk.

\begin{tabular}{l|l}
\hline \multicolumn{1}{c|}{ Tingkat } & \multicolumn{1}{c}{ Yang ingin dilihat } \\
\hline Kata & $\begin{array}{c}\text { Pilihan kosakata yang dipakai untuk menggambarkan peristiwa. } \\
\text { - Pilihan kata memiliki tujuan: (a) membuat klasifikasi; (b) membatasi pandangan; (c) } \\
\text { memenangkan pertarungan wacana; (d) marginalisasi; (e) menguatkan pihak sendiri } \\
\text { Kalimat }\end{array}$ \\
& $\begin{array}{l}\text { - Bagaimana peristiwa digambarkan lewat rangkaian kata. } \\
\text { - Ada tiga model rangkaian yaitu: (a) transitif, ada hal yang dianggap sebagai penyebab } \\
\text { dan sebagian dianggap sebagai akibat akan suatu tindakan; (b) intransitif, terdapat } \\
\text { aktor yang dihubungkan dengan suatu proses namun tanpa menjelaskan akibat atau } \\
\text { objek yang dikenai; (c) relasional, bersifat ekuatif yaitu menghubungkan dua hal yang } \\
\text { merupakan sama-sama kata benda, dan bersifat atributif yaitu pemberian kata sifat } \\
\text { pada kata bernada untuk menunjukkan suatu kualitas atau penilaian tertentu. }\end{array}$ \\
& \\
\hline
\end{tabular}

Adapun alur analisis tulisan ini adalah sebagai berikut:

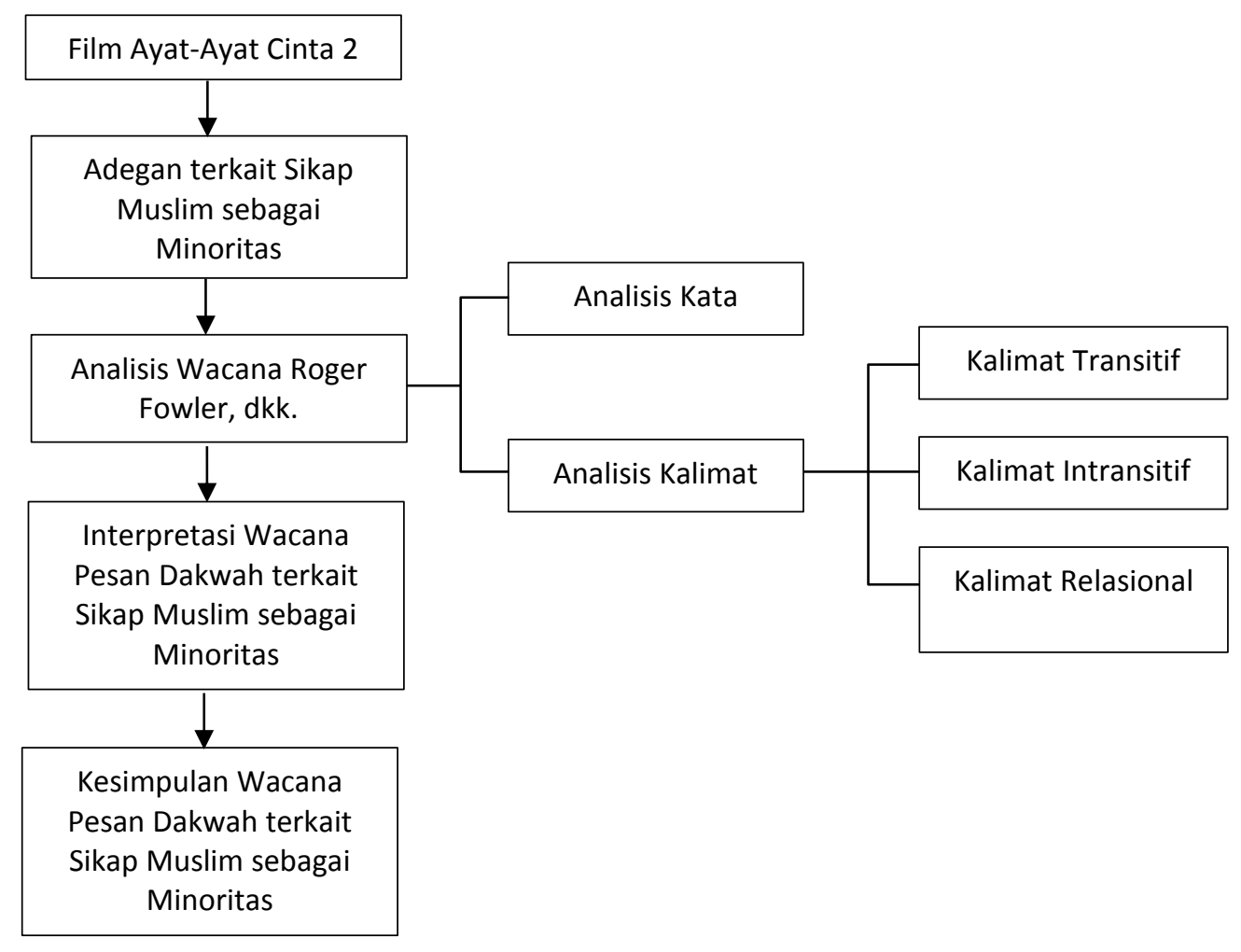

Sketsa 1 - Alur Analisis Studi

\footnotetext{
22 Ibid., 164-165.
} 


\section{Gambaran Umum Film AAC 2}

Konflik film AAC 2 berpusat pada tokoh utamanya Fahri, yang saat itu telah menjadi seorang dosen di salah satu universitas di Edinburgh, Skotlandia. Selain itu Fahri juga memiliki usaha minimarket. Namun Fahri hidup sendiri, karena istrinya, Aisha, tidak ada kejelasan kabar usai menjadi relawan di Palestina. Fahri sudah mencari ke mana-mana tetapi tidak membuahkan hasil. Aisha masih belum ditemukan. Apakah masih hidup atau sudah meninggal, tidak ada kejelasan. Dalam menjalani kehidupannya yang sendiri itulah, Fahri menghadapi berbagai dinamika, salah satunya dengan tetangga-tetangganya yang nonmuslim.

Secara umum digambarkan ada stigma negatif dari masyarakat nonmuslim kepada umat Islam, sebagai akibat dari perilaku teroris oknum yang mengatasnamakan Islam. Stigma tersebut muncul karena ada kasus pemboman di London, Inggris. Salah seorang tetangga Fahri adalah anak dari korban bom teroris tersebut, yaitu Keira dan Jason, sehingga mereka sangat membenci Islam, termasuk akhirnya kepada Fahri. Selain itu, ada seorang Yahudi tetangga Fahri, Nenek Catarina, yang juga memiliki pandangan negatif terhadap Islam, dan ada Brenda, seorang pengacara yang digambarkan suka mabuk-mabukan. Sehingga Fahri tinggal di lingkungan mayoritas nonmuslim dan beragam.

Dalam kesehariannya, Fahri dibantu oleh supirnya bernama Hulusi, yang berasal dari Turki. Seorang preman yang pernah diselamatkan oleh Fahri. Selain itu ada yang bernama Misbach, sahabatnya Fahri, yang untuk sementara waktu tinggal di rumahnya. Fahri juga menampung seorang perempuan bercadar dan cacat wajahnya, yang ketika itu diusir polisi karena berjualan di depan masjid, menjadi pembantu di rumahnya. Perempuan itu bernama Sabina.

Sementara itu, setelah sekian lama, Fahri masih belum jua menemukan Aisha. Sepupu Aisha, bernama Hulya ternyata juga menaruh hati pada Fahri. Ayah Aisha kemudian meminta Fahri menerima kenyataan bahwa Aisha telah meninggal, dan mau menikahi Hulya. Disitulah dilema Fahri, namun ia akhirnya memutuskan untuk menikahi Hulya. Fahri tidak menyadari bahwa Sabina sejatinya adalah Aisha. la sengaja merusak muka dan alat vitalnya agar tidak menjadi korban kekejaman tentara Israel. Cerita berakhir ketika Fahri dan Hulya, karena suatu hal, menyadari bahwa Sabina adalah Aisha. Hulya kemudian meninggal karena ditusuk oleh penjahat bernama Bahadur. Sebelum meninggal, Hulya mendonorkan wajahnya untuk Aisha, sehingga dilakukanlah operasi transfer wajah. Akhirnya, Fahri dan Aisha kembali hidup bersama.

\section{Adegan Terkait Sikap Fahri sebagai Muslim Minoritas dalam Film AAC2}

Studi ini memfokuskan pada wacana pesan dakwah terkait sikap muslim sebagai minoritas. Dalam hal ini diwakili 
oleh sosok Fahri, yang ditampilkan sebagai seorang muslim yang saleh. Adegan-adegan yang akan dianalisis adalah terkait sikap Fahri kepada para tetangganya yang mayoritas nonmuslim. Sehingga tidak semua adegan dianalisis.

Adegan 1: Fahri menghentikan mobilnya di tengah jalan untuk menawarkan tumpangan kepada tetangganya yang sedang menunggu bus. $^{23} \mathrm{Hal}$ ini dimasukkan sebagai realitas kehidupan kaum minoritas karena hal ini menunjukkan sikap keseharian yang dilakukan oleh Fahri dalam kondisi masyarakatnya yang nonmuslim. Situasi dialog ini terjadi di pinggir sebuah jalan, dimana Fahri mengendarai mobil sedangkan tetangganya tersebut menunggu di pinggir jalan untuk mendapatkan tumpangan.

Fahri: "Selamat sore Keira, saya Fahri, kita tetangga. Dan kalau kamu dalam perjalanan pulang, kita sejalur."

Keira: "Ya, so?"

Fahri: "Saya ingin menawarkan kamu untuk ikut ke mobil saya."

Hulusi: "Dia sepertinya tidak tertarik, mari kita..." (gerak badan menarik Fahri) Fahri: "Keira, kamu yakin? Tidak ada salahnya kalau kamu."

Keira: "Saya bisa mengurus diri sendiri." Hulusi: "Dia bisa mengurus dirinya sendiri, mari kita pulang."

Fahri: "Saya hanya menawarkan bantuan. Siapa tahu kamu mau ikut."

Keira: "Kamu sebaiknya pergi atau saya panggil polisi."

Hulusi: "Hey, Keira, Fahri bermaksud baik, kenapa kamu seperti itu."

Keira: "Siapa tahu kamu berbuat buruk."
Fahri: "Keira, semoga Tuhan menjadi saksi, Saya tidak berniat buruk."

Keira: "Kebiasaan kalian. Selalu mengatasnamakan Tuhan atas tindakan kalian. Bahkan saat kalian melakukan teror, pemboman dan pembantaian."

Hulusi: "Hey, jangan kurang ajar kamu Keira."

Fahri: "Tenang Hulusi. Saya hanya ingin menawaran bantuan Keira. Kalau kamu tidak mau tidak apa-apa. Semoga harimu menyenangkan."

Adegan 2: Adegan Fahri ketika melihat mobilnya ada tulisan 'monster' dan Fahri memilih menggunakan bus dan menyuruh Hulusi untuk mengurusnya ke bengkel. ${ }^{24} \mathrm{Hal}$ ini dimasukkan sebagai realitas kehidupan kaum minoritas karena menunjukkan sikap keseharian yang dialami oleh kalangan minoritas muslim yang mungkin mendapatkan teror terhadap keberadaannya dalam masyarakat tersebut, sebagai akibat stigma negatif terhadap Islam. Hal ini dilakukan oleh pihak-pihak yang mungkin tidak mengharapkan keberadaan kaum muslim di dalam lingkungan tersebut.

Hulusi: "Allah, Allah..." (ketika melihat bagian kiri mobil Fahri terdapat sebuah tulisan 'Monster' dengan cat warna putih). "Orang-orang itu sudah keterlaluan."

Fahri: "Ada apa Hulusi?" (Fahri datang dengan Misbah)

Hulusi: "Tidak apa-apa Hoca, aman."

Misbah: "Innalillahi. Hulusi ini kamu apakan?"

Hulusi: "Saya? Ini bukan saya."

Misbah: "Lha tugas kamu apa?"

${ }^{24}$ Film Ayat-Ayat Cinta 2, menit 13:54. 
Fahri: "Cukup. Hulusi tolong kamu bawa mobil ke bengkel biar saya naik bus saja." Hulusi: "Hoca jangan."

Fahri: "Tidak. Misbah kamu bisa ikut Hulusi sekalian menghafal jalan disini. Assalamualaikum."

Hulusi dan Misbah: "Waalaikum salam."

Adegan 3: Adegan Fahri menolong tetangganya Brenda yang sehabis pulang pesta dan mabuk, ditidurkan dengan diberikan selimut dan bantal. ${ }^{25} \mathrm{Hal}$ ini dimasukkan sebagai realitas kehidupan minoritas muslim, karena menunjukkan sikap terhadap lingkungannya yang sedang membutuhkan pertolongan tanpa melihat siapa orang tersebut, apakah muslim atau nonmuslim.

Fahri: "Hulusi.."

Hulusi: "Ada apa Hoca?"

Fahri: "Brenda..."

Kemudian keduanya menuju depan rumah Brenda, dan membantu Brenda yang mabuk untuk ditidurkan di kursi depan rumahnya

Fahri: "Hulusi, tolong ambilkan bantal dan selimut dari rumah."

Hulusi: "Tapi dia sepertinya sudah nyaman Hoca."

Fahri: "Dia bisa mati kedinginan disini, ayo cepat."

Saat Hulusi dan Fahri memberikan selimut dan bantal nenek Catarina melihat Fahri dan Hulusi dari halaman rumahnya dan kemudian masuk kembali.

Adegan 4: Adegan Fahri menyapa salah satu tetangganya Nenek Catarina yang hendak menuju tempat ibadahnya (orang Yahudi) dan menawarkan tumpangan untuk ke sana. ${ }^{26}$ Hal ini dimasukkan sebagai realitas kehidupan minoritas muslim, karena menunjukkan sikap terhadap tetangga untuk memberikan bantuan kepada pihak yang dipandang membutuhkan. Dialog ini terjadi di depan rumah Fahri, dimana rumah Nenek Catarina berada di depan rumah Fahri, dan Fahri juga bersikap mendatangi ke seberang jalan untuk menemuinya, tidak hanya disapa dari depan rumahnya saja.

Fahri: "Nenek Catarina. Pagi Nek. Kakinya masih sakit, Nek. Nenek mau kemana?" Nenek: "Untung saja kaki saya sedang sakit. Kalau tidak, kalian saya labrak tadi malam. Mengambil kesempatan pada wanita yang tidak berdaya."

Fahri: "Maksud Nenek apa?"

Nenek: "Brenda. Semalam dia mabuk dan saya melihat apa yang kalian perbuat dengan dia."

Fahri: "Nenek salah paham."

Brenda: (keluar dari rumah dengan membawa bantal) "Fahri, aku dengar kau. Selamat pagi."

Fahri: "Pagi"

Brenda: "Fahri, ini punyamu." (sambil menyerahkan bantal dan selimut kepada Fahri). "Terima kasih atas bantuannya semalam. Dan maaf, berkali-kali merepotkan. Rekan kerjaku ulang tahun, jadi pengacara sedang kumpul, acaranya minum-minum terus, dan seperti biasa, saya lupa diri jika ada pesta."

Fahri: "Lain kali kamu harus lebih hatihati."

Brenda: "Ya pasti" (kemudian pergi meninggalkan Fahri dan nenek) Nenek: "Sepertinya saya salah paham."

${ }^{26}$ Film Ayat-Ayat Cinta 2, menit 30:27. 
Fahri: "Nenek mau kemana? Biar kami antar"

Nenek: "Saya mau ibadah ke synagogue." (tempat ibadah kaum Yahudi)

Fahri: "Baik, mari Nek."

Adegan 5: Adegan Fahri memarahi Hulusi karena menolak memberikan tumpangan kepada Nenek Catarina, hanya karena seorang Yahudi dan menyuruh Hulusi untuk tidak melakukan hal yang sama, karena Nabi juga sering membantu tetangganya. ${ }^{27} \mathrm{Hal}$ ini dimasukkan kedalam realitas minoritas muslim yang menunjukkan bagaimana paradigma perilaku muslim yang seharusnya terhadap tetangganya sekalipun nonmuslim. Dialog ini terjadi di dalam rumah dimana hanya terdapat tiga orang saja.

Fahri: "Kenapa kamu menolak untuk mengantarkan Nenek Catarina, Hulusi?" Misbah: "Menurutku Iho ya, apa yang dilakuin Hulusi ini uda bener. Kamu tidak liat bagaimana perlakuan mereka." (langsung dijawab oleh Fahri)

Fahri: "Saya tidak mempermasalahkan sikap mereka ke kita. Itu hak mereka untuk curiga. Yang saya kecewa kenapa Hulusi melakukan hal yang sama ke Nenek Catarina."

Hulusi: "Nenek itu Yahudi... Yahudi."

Fahri: "Nenek Catarina itu tetangga kita. Kita harus membantunya. Membantu tetangga itu ajaran Rasullullah. Apa kamu yang lupa? Yang kita tentang itu zionisnya, kezalimannya, bukan kaum Yahudinya apalagi orang per orangnya. Kalau kita melakukan hal yang sama ke

27 Film Ayat-Ayat Cinta 2, menit 33:22.
Nenek Catarina apa bedanya kita dengan Zionis di Palestina?"

Adegan 6: Adegan Fahri dan Hulusi membantu Nenek Catarina yang diusir dari rumahnya oleh anaknya sendiri. ${ }^{28} \mathrm{Hal}$ ini menunjukkan perilaku menolong tetangga sekalipun sebagai kaum minoritas. Dialog ini terjadi di depan rumah nenek, Fahri yang kemudian menghampiri dan tidak hanya melihat saja di depan rumah. Dibantu dengan rekannya mereka kemudian membantu Nenek Catrina.

Fahri: "Nenek..." (membantu nenek berdiri dengan Hulusi). "Siapa dia Nek? Kenapa dia mengusir Nenek dari rumah?" Nenek: Baruch, anak tiri saya. Dia menginginkan rumah ini untuk membayar hutang-hutangnya."

Fahri: "Tapi dia tidak bisa seenaknya mengusir nenek seperti ini."

Nenek: "Rumah ini sudah dijual tanpa sepengetahuan saya, Fahri."

Fahri: "Hulusi, bawa nenek ke rumah kita, biar saya yang bicara dengan Baruch."

Nenek: "Jangan Fahri. Dia sumber masalah sejak dulu. Dia dikeluarkan dari tentara Israel karena kelakuannya."

Lelaki: "Keluar dari sini!" (sambil melemparkan koper)

Fahri: "Astaghfirullah...! Hey jangan keterlaluan. Bukan begitu cara memperlakukan perempuan. Apalagi ibumu sendiri."

Lelaki: "Kamu siapa? Kamu muslim ya?" (sambil mendorong ke arah Fahri)

Fahri: "Anda tidak perlu bermain kasar seperti itu. Nenek Catarina adalah

\footnotetext{
${ }^{28}$ Film Ayat-Ayat Cinta 2, menit 40:16.
} 
sahabat saya. Bahkan sudah seperti ibu saya sendiri."

Lelaki: "Bagus, kamu bisa tampung dia sekalian."

Adegan 7: Adegan Fahri menemui pencuri di supermarketnya yang ternyata adalah tetangganya sendiri, Jason. Fahri tidak menghukumnya, melainkan mengajaknya untuk minum milkshakes bersama. ${ }^{29} \mathrm{Hal}$ ini dipandang bisa menjadi realitas kehidupan muslim minoritas ketika menyikapi masalah keseharian yang berhubungan dengan tetangganya yang merupakan nonmuslim. Dalam kondisi ini Jason tidak mengetahui bahwa pemilik supermarket itu adalah Fahri. Dialog ini dilakukan di sebuah restoran.

Fahri: "Saya dengar, milkshake disini, milkshake yang paling enak. Ayo minum. Oke. (kemudian meminum). Hmm..., luar biasa. Ayo jason."

Jason: "Buat apa kita ke sini, hah? Langsung saja kita ke kantor polisi. Saya tidak takut."

Fahri: "Aku tahu kamu anak yang tangguh. Tapi bagaimana dengan keluargamu? Ibumu? Apa perasaannya saat dia tahu kamu dipenjara hanya karena mencuri snacks?"

Jason: "Omong kosong!"

Fahri: "Ayo berteman, Jason. Duduk. Please. Setelah ini jika kamu butuh sesuatu apapun, selama masih ada di minimart saya, bisa kamu ambil. Gratis." Jason: "Kenapa kamu bersikap begitu baik?"

\footnotetext{
${ }^{29}$ Film Ayat-Ayat Cinta 2, menit 45:41.
}

Fahri: "Saya tidak mau punya musuh. Apalagi dengan tetangga saya sendiri." (sambil menawarkan jabatan tangan) Jason: "Tidak. Kamu yang memulai." Fahri: "Maksudmu?" Jason: "Kalian teroris. Kalian yang bunuh ayah kami. Ayah kami cuma ingin memberikan kami oleh-oleh ketika bom itu meledak di London. Sejak ayah kami tidak ada. Ibu yang harus menghidupi kita semua. Keira tidak bisa melanjutkan sekolah musiknya. Dan saya, saya dikeluarkan dari sekolah bola."

Adegan 8: Adegan ketika Hulusi memergoki Keira sedang melakukan semprot cat ke mobil Fahri, dan Fahri memberikan kebebasan kepada Keira jika memang itu yang bisa membuatnya puas. $^{30}$ Hal ini dimasukkan karena dipandang sebagai realitas kehidupan muslim minoritas dimana salah satunya adalah mendapatkan teror dan bisa merugikan secara materiel. Dialog ini terjadi di halaman rumah Fahri, terjadi di tengah malam dan Fahri dibantu oleh Hulusi dan Misbah.

Hulusi: "Hei, hentikan!" (sambil berlari menuju mobil dan Misbah mengejar dari sisi berlawanan)

Hulusi: "Berhenti kamu, Keira?"

Keira: "Lepaskan aku"

Fahri: "Lepaskan dia Hulusi." (Fahri keluar dari rumah)

Hulusi: "Tidak Hoca, pelaku vandal seperti ini wajib kita bawa ke polisi."

Keira: "Laporkan saja, saya tidak takut. Saya akan ceritakan semuanya. Para polisi itu akan mendukung apa yang saya

\footnotetext{
${ }^{30}$ Film Ayat-Ayat Cinta 2, menit 01:20:55.
} 
lakukan karena mereka juga benci sama kalian."

Hulusi: "Hei Keira, kamu ini kenapa? Kami tidak pernah melakukan apapun yang menyakiti kalian."

Fahri: "Cukup, lepaskan dia."

Keira: "Saya tidak butuh belas kasihanmu. Laporkan saja. Penjarakan saya seperti yang kamu mau."

Fahri: "Kalau memang itu yang saya mau. Sudah lama kamu saya laporkan ke polisi Keira."

Misbah: "Jadi kamu sudah tahu dia pelakunya?"

Keira: "Kamu pikir saya akan berterima kasih? Meminta maaf?"

Fahri: "Tidak Keira. Saya tahu rasanya kehilangan. Kehilangan yang membuat kita marah terhadap dunia. Saya pun kehilangan istri saya. Dia jadi korban di Palestina. Kamu merindukan ayahmu. Saya pun merindukan istri saya. Sekarang pulanglah. Atau kalau mencoret mobil saya membuatmu lebih lega, silahkan. Tapi kalau itu hanya membuatmu semakin mendendam dan marah, untuk apa? Itu tidak akan bisa mengembalikan orang yang kita sayang."

\section{Analisis Wacana Pesan Dakwah Film AAC2}

\section{Analisis Penggunaan Kata}

Dalam pemilihan dan penggunaan kata dalam adegan film tersebut terdapat beberapa kata yang menunjukkan sikap muslim terhadap lingkungan sekitarnya, berdasarkan adegannya, pada adegan 1 terdapat penggunaan kata 'tetangga' dan 'tidak berniat buruk', pada adegan 4 terdapat penggunaan kata 'salah paham', pada adegan 5 terdapat penggunaan kata 'zionisnya' dan 'kezalimannya', pada adegan 7 terdapat penggunaan kata 'berteman', 'gratis', dan 'musuh'. Berdasarkan penggunaan kata yang dimunculkan dalam film, jika dikaitkan dengan sikap muslim terhadap lingkungannya yang merupakan kaum nonmuslim adalah bahwa, pertama, kalangan muslim memiliki keinginan untuk bisa membantu lingkungan sekitarnya sesuai dengan kemampuan yang dimiliki. Hal ini tecermin pada kata 'tetangga', 'tidak berniat buruk'. Kata tersebut bisa bermakna bahwa ketika berinteraksi dengan lingkungan sekitarnya kaum muslim menekankan bahwa mereka adalah tetangga, sehingga ketika ada tetangga yang membutuhkan akan dibantu dan kaum muslim ketika membantu tetangganya yang merupakan kalangan nonmuslim sebenarnya murni karena ingin membantu dan tidak ada keinginan untuk merugikan tetangganya sendiri.

Kedua, kalangan muslim memiliki pandangan bahwa kaum muslim lebih memilih berteman dibandingkan menjadi musuh khususnya terhadap lingkungannya yang merupakan kalangan nonmuslim. Hal ini tecermin pada penggunaan kata 'salah paham', 'berteman', 'gratis', dan 'musuh'. Penggunaan kata tersebut memiliki makna bahwa ketika ada pandangan buruk kepada kaum muslim dipandang sebagai sebuah kesalahpahaman, karena kaum muslim tidak berniat buruk kepada lingkungan sekitarnya. Hal lainnya menjelaskan bahwa kaum muslim 
berusaha untuk membantu kalangan nonmuslim dengan memberikan apa yang dimiliki ketika dibutuhkan oleh tetangganya secara gratis atau tidak perlu membayar. Gratis menunjukkan bahwa hubungan membantu yang dilakukan oleh kaum muslim tidak berkaitan dengan aspek ekonomi, karena jika dilihat pemberian secara gratis tentu akan merugikan karena tidak ada timbal balik di antara kedua pihak, namun hal ini tidak menjadi dasar perilaku membantu yang dilakukan oleh kaum muslim.

Ketiga, sikap membenci atau menjauhi kaum nonmuslim tidak ditentukan oleh apa agama yang dianut, melainkan dari sikap yang dimunculkan. Hal ini tecermin pada penggunaan kata 'zionisnya', 'kezalimannya'. Penggunaan kata ini hendak menunjukkan bahwa dasar hubungan kaum muslim dengan nonmuslim sebagai sebuah tetangga adalah karena dasar perilakunya, bukan karena apa agamanya. Secara tidak langsung hal ini menunjukkan bahwa selama perilaku yang dilakukan baik, maka kaum muslim tidak akan mempermasalahkan identitas agamanya. Sebaliknya ketika perilaku yang dilakukan buruk maka umat muslim hanya akan menilai perilakunya tanpa menghubungkan kepada agama tertentu. Sehingga dasar penilaiannya lebih kepada sikap dan perilaku dari seseorang tersebut terlepas apapun agama yang dianut.

Seluruh pernyataan tersebut memberikan sebuah wacana pesan dakwah mengenai sikap muslim terhadap kalangan nonmuslim ketika berada dalam kondisi minoritas yakni bahwa dimanapun kaum muslim memiliki kecenderungan untuk berperilaku secara baik kepada lingkungan sekitarnya walaupun lingkungannya adalah kalangan nonmuslim, perilaku baik ini juga didasarkan untuk memiliki hubungan yang baik dengan lingkungannya dan tidak hendak mencari kepentingan tertentu yang bisa merugikan salah satu pihak. Penyampaian tersebut memberikan sebuah pesan kepada masyarakat bahwa harusnya kaum muslim memiliki perilaku yang serupa ketika berada dalam kondisi minoritas sekalipun, bahwa niat dan perilaku baik harus selalu dijunjung dimanapun kaum muslim berada. Berikutnya adalah bahwa umat muslim akan berusaha membantu lingkungannya seoptimal mungkin dengan kemampuan yang dimiliki. Dalam konteks film karena Fahri memiliki supermarket maka dia mengijinkan tetangganya untuk mengambil secara gratis. Situasi ini menunjukkan bahwa membantu sebenarnya harus sesuai dengan kemampuan dan juga kebutuhan yang dibantu. Realitas membantu ini akan membuat hubungan antara kaum muslim dengan lingkungannya menjadi semakin erat dan terjaga sehingga tidak ada kesalahpahaman yang bisa merusak interaksi keduanya dalam interaksi sosial sehari-hari. Penyampaian tersebut memberikan sebuah pesan bahwa perilaku menolong tetangga merupakan hal yang dijunjung dalam agama Islam, bentuk menolong itu juga harus tetap disesuaikan dengan kemampuan yang 
dimiliki dan sesuai kebutuhan yang ditolong. Dengan pesan semacam ini tentunya tidak menjadi alasan kaum muslim untuk tidak membantu lingkungannya, yang perlu diperhatikan salah satunya adalah bentuk bantuan yang didasarkan kepada kemampuannya.

Terakhir, umat muslim memiliki sebuah pandangan mengenai kaum nonmuslim dimana penekanan kebenciannya bukan dilekatkan karena identitas agamanya, melainkan karena perilaku yang dilakukan. Pernyataan ini menunjukkan bahwa keliru jika memosisikan suatu agama sebagai suatu yang dibenci, karena yang dibenci haruslah terkait perilakunya. Umat muslim dengan hal ini diberikan pemahaman bahwa kebencian dan renggangnya hubungan dengan lingkungan atas dasar identitas agama adalah suatu yang salah dan harusnya tidak diteruskan. Sehingga, dengan adanya penyataan tersebut membuat kaum muslim memiliki paradigma yang berbeda ketika berinteraksi dengan kalangan nonmuslim, tidak perlu membenci atau menghindar selama memang perilaku yang dimunculkan tidak merugikan umat muslim.

\section{Analisis Penggunaan Kalimat}

Dalam penggunaan kalimat dalam dialog, terdapat beberapa kondisi yang memunculkan suatu wacana mengenai sikap muslim. Pertama, memiliki keinginan untuk menolong tetangganya ketika sedang kesusahan, terdapat pada adegan 1 ketika Fahri mengatakan, "Saya hanya ingin menawaran bantuan keira. Kalau kamu tidak mau tidak apa-apa.
Semoga harimu menyenangkan", pada adegan 3 ketika mengatakan, "Hulusi, tolong ambilkan bantal dan selimut dari rumah, dia bisa mati kedinginan disini, ayo cepat", pada adegan 4 ketika mengatakan, "Kakinya masih sakit nek. Nenek mau kemana? Biar kami antar", pada adegan 6 ketika mengatakan, "Bawa nenek ke rumah kita, biar saya yang bicara dengan Baruch". Berdasarkan data tersebut, memberikan gambaran bagaimana sikap seorang muslim di dalam kehidupan sehariharinya yang bersedia untuk membantu tetangganya yang sedang kesusahan. Yang menarik dari beberapa ucapan kalimat itu jika dilihat dari kronologis dialog, menunjukkan bahwa umat muslim selalu memiliki inisiatif untuk membantu terlebih dahulu, kondisi ini memberikan suatu pesan dakwah bahwa umat Islam harus menjadi pihak yang memiliki inisiatif untuk membantu tetangga di sekitar rumahnya, tidak perlu tetangganya meminta bantuan terlebih dahulu untuk kemudian ditolong. Umat Islam harus menjadi pihak yang aktif untuk memberikan bantuan kepada tetangga yang membutuhkan pertolongan.

Aspek lainnya adalah bahwa ketika seorang muslim menawarkan bantuan dan pihak yang ditawarkan bantuan menolak maka umat Islam tidak perlu kecewa atau memaksakan tawarannya. Dalam film itu terlihat ketika Fahri menawarkan bantuan kepada tetangganya, Keira, dan ia menolaknya. Hal yang dilakukan Fahri tidak memaksa dan marah ketika tawarannya ditolak, hal 
yang dilakukan oleh Fahri adalah mendoakan agar bisa melalui hari dengan menyenangkan. Realitas ini menguatkan suatu pesan dakwah ketika tawaran bantuan ditolak oleh kalangan nonmuslim, kaum muslim tidak perlu merasa kecewa dan marah ketika tawarannya ditolak, karena penolakan itu adalah hak dari pihak yang ditawarkan bantuan, sikap yang harus dilakukan adalah tetap berdoa atau setidaknya mendoakan bagi pihak tersebut agar tidak terjadi apa-apa dikemudian hari. Pesan dakwah yang kuat ditekankan dengan sikap yang rendah hati menerima tawarannya ditolak dan tanpa perlu memiliki prasangka negatif ataupun menjadi tersinggung ketika tawarannya ditolak. Kondisi ini bisa menunjukkan bahwa Islam menawarkan ajaran yang mulia, yakni ketika ada yang membutuhkan pertolongan dirinya memiliki kesadaran untuk memberikan bantuan sebelum orang tersebut memintanya, kemudian ketika tawarannya ditolak maka yang dilakukan adalah mendoakan agar orang tersebut tidak mengalami hal yang buruk atau negatif.

Kedua, sikap ketika ada perilaku dari lingkungan yang merugikan dirinya, terdapat pada adegan 2 ketika mengatakan, "Hulusi tolong kamu bawa mobil ke bengkel biar saya naik bus saja", kemudian pada adegan 5, "Saya tidak mempermasalahkan sikap mereka ke kita. Itu hak mereka untuk curiga. Yang saya kecewa kenapa Hulusi melakukan hal yang sama ke Nenek Catarina, Nenek Catarina itu tetangga kita. Kita harus membantunya. Membantu tetangga itu ajaran Rasullullah." Pada adegan 8 ketika mengatakan, "Kalau mencoret mobil saya membuatmu lebih lega, silahkan. Tapi kalau itu hanya membuatmu semakin mendendam dan marah, untuk apa? Itu tidak akan bisa mengembalikan orang yang kita sayang". Berdasarkan data tersebut, memberikan suatu gambaran bagaimana seharusnya sikap seorang muslim ketika ada perilaku atau tindakan dari lingkungan yang memberikan kerugian secara langsung, baik secara materiel maupun psikologis. Kondisi tersebut tecermin dari ucapan dan sikap yang dimunculkan oleh Fahri ketika mobilnya dirusak dengan cat, sikap yang dimunculkan adalah tidak menghardik ataupun memaki lingkungan sekitar yang mungkin dipandang melakukan hal tersebut melainkan melakukan pemecahan masalah dengan memperbaiki mobilnya.

Kemudian sikap lainnya ditunjukkan ketika memberikan respon mengenai kecurigaan sikap tetangganya yang nonmuslim terhadap kaum muslim, sikap yang ditawarkan dalam film adalah menunjukkan bahwa umat muslim tidak perlu memberikan atau membalas dengan hal yang sama kepada kaum nonmuslim, yang ditekankan dalam situasi ini adalah bahwa seorang muslim harus memiliki sikap yang baik terhadap lingkungannya. Perbuatan itu dipandang sebagai salah satu ajaran Rasul, kondisi ini menunjukkan suatu legitimasi bahwa ketika seorang muslim tidak melakukan hal yang sama kepada kaum nonmuslim itu artinya mengikuti ajaran Rasul, namun 
hal ini secara tidak langsung bisa bermakna bahwa ketika yang dilakukan justru memberikan kecurigaan yang sama kepada kaum nonmuslim maka sebenarnya umat muslim tidak mengikuti ajaran Rasul. Hal lain yang terdapat dalam dialog tersebut adalah bahwa seorang muslim ketika ada kaum nonmuslim yang memiliki kebencian kepada kaum muslim maka sikap yang ditunjukkan adalah dengan berdialog dan mengajak kaum nonmuslim untuk menghayati kembali apakah perbuatan yang dilakukan tersebut adalah tindakan yang tepat.

Dalam konteks tersebut, terdapat suatu pesan dakwah yang disampaikan yakni bahwa sudah menjadi kewajiban seorang muslim untuk memberikan ruang untuk berdialog dengan kaum nonmuslim jika kondisinya adalah kaum nonmuslim memiliki prasangka negatif terhadap kalangan muslim, baik secara perbuatan maupun ucapan. Sikap yang ditonjolkan adalah dengan tidak membalas kecurigaan itu dengan kecurigaan lagi, karena jika dibalas dengan kecurigaan lagi maka akan menjadi sebuah siklus yang tidak akan pernah terputus, oleh karena itu usaha untuk memutus siklus negatif itu adalah dengan memberikan ruang dan mengajak kaum nonmuslim untuk melakukan dialog dan mengajak untuk berdamai. Langkah ini dipandang sebagai suatu pesan dakwah yang hendak ditekankan kepada penonton ketika menonton film ini dengan harapan pemikiran dan sikap tersebut bisa diterima dan diterapkan dalam kehidupan.
Ketiga, berkaitan dengan ikatan atau hubungan yang digambarkan oleh seorang muslim terhadap lingkungannya, terdapat pada adegan 6 ketika mengatakan, "Bukan begitu cara memperlakukan perempuan. Apalagi ibumu sendiri, Nenek Catarina adalah sahabat saya. Bahkan sudah seperti ibu saya sendiri". Berdasarkan data tersebut, menunjukkan bahwa perasaan ataupun hubungan yang ada di dalam benak seorang muslim minoritas terhadap lingkungannya yang merupakan kaum nonmuslim. Pernyataan yang ditunjukkan cukup jelas yakni bahwa ikatan yang dimiliki kaum muslim terhadap tetangganya yang merupakan kalangan nonmuslim digambarkan sebagai seorang keluarga, yang merupakan seperti hubungan keturunan. Pemberian gambaran ini hendak menunjukkan suatu pesan dakwah bahwa kaum muslim memiliki pandangan untuk menjaga tetangganya jika memang ada yang mengganggu atau bertindak sewenangwenang terlebih kepada wanita. Ikatan sahabat dan juga ibu anak adalah ikatan yang istimewa dan memiliki makna yang dalam. Sahabat adalah seseorang yang selalu ada di kala kondisi sedang sulit atau senang, mau menerima kekurangan dan kelebihan sahabatnya, dan yang paling penting adalah hubungan yang terjalin adalah hubungan yang tidak didasari oleh kondisi identitas agama tertentu. Dengan kata lain bahwa umat Islam memiliki situasi kehidupan yang merasa bahwa tetangga yang nonmuslim adalah sahabat dan keluarganya sendiri, sehingga ada upaya untuk saling melindungi, membantu dan berkorban untuk orang 
tersebut. Sehingga jelas makna dari pernyataan tersebut adalah bahwa umat muslim memiliki paradigma bahwa tetangga sekitar adalah keluarganya atau orang yang akan dilindungi, dibantu ketika membutuhkan pertolongan dengan tidak terlalu memperhatikan identitas agamanya. Pesan ini jika dihubungkan dengan sikap muslim terhadap kaum nonmuslim masih sesuai dimana tidak ada larangan untuk berbuat baik atau bekerja sama selama tidak merugikan umat muslim.

\section{Kesimpulan}

Dari penjelasan tersebut dapat diketahui bahwa pesan dakwah yang didapatkan dari analisis wacana film AAC 2 berdasarkan kata dan kalimat mengenai sikap muslim sebagai minoritas di lingkungannya, secara umum adalah tetap berinteraksi sosial dengan lingkungan sekitar, bersedia membantu tetangganya yang membutuhkan, sekalipun berbeda agamanya. Jika ada sikap tetangga yang merugikan, maka tidak serta-merta menghujat atau merugikan balik, tetapi mencoba memahami persoalan tersebut secara utuh, pemberian maaf sangat dikedepankan. Idealnya seorang muslim memosisikan tetangganya seperti sahabat dan keluarga sendiri. Berikutnya adalah bahwa sikap menjauhi suatu kaum terlebih tetangga tidak ditentukan oleh agama yang dianut melainkan bagaimana sikap yang dimunculkan. Ketika sikapnya tidak merugikan maka sudah sepatutnya kaum muslim tidak membenci atau menolak berinteraksi termasuk memberikan bantuan jika memang dibutuhkan. Hal tersebut sejalan dengan prinsip ajaran Islam sebagai rahmatan lil alamiin.

Hasil studi ini merekomendasikan perlunya bagi para pelaku dakwah untuk menggemakan tema-tema pesan dakwah yang mencerminkan ajaran Islam yang damai, membawa pada kebaikan, dan rahmat bagi semua, baik ketika Islam sebagai minoritas maupun mayoritas. Pesan-pesan dakwah tersebut dapat disajikan dalam berbagai media, seperti: film, sinetron, novel, musik, dan lain-lain. Studi lanjutan terkait analisis wacana pesan dakwah film AAC 2 perlu dilakukan, mengingat studi ini hanya mengambil salah satu aspek saja dari beberapa pesan dalam film tersebut. Demikian pula studi analisis wacana terhadap film-film yang bernuansa dakwah lainnya, guna memperkaya khazanah keilmuan komunikasi dakwah.

\section{Bibliografi}

n.d. Ayat-Ayat Cinta 2.

Aziz, Moh. Ali. Ilmu Dakwah. Jakarta: Kencana, 2009.

BBC. "Lebih dari Setengah Kejahatan Kebencian di Inggris Menyasar Umat Muslim." bbc.com, Januari 9, 2019. http://www.bbc.com/indonesia/dunia-445884930. 
Dirun. "Hubungan Muslim Non-Muslim dalam Interaksi Sosial (Studi Analisis Penafsiran Thabathabai dalam Kitab Tafsir al-mizan)." Skripsi, UIN Walisongo Semarang, 2015. Eriyanto. Analisis Wacana. Yogyakarta: LKiS Yogyakarta, 2006.

Ilprima, Ricca Junia. "Analisis Wacana Pesan Toleransi Antarumat Beragama Dalam Novel Ayat-Ayat Cinta 2 karya Habiburrahman El Shirazy." Skripsi, UIN Syarif Hiyatullah Jakarta, 2016.

Ishaq, Ropingi el. Pengantar IImu Dakwah; Studi Komprehensif Dakwah dari Teori ke Praktik. Malang: Madani, 2016.

Kusumawati, Utami Diah. "Muhammadiyah Imbau Umat Muslim Tak Obral Ucapan $\begin{array}{lllll}\text { "Kafir". CNN Indonesia, Mei } & 2019 .\end{array}$ http://www.cnnindonesia.com/nasional/20150808112900-20-

70816/muhammadiyah-imbau-umat-muslim-tak-obral-ucapan-kafir.

Mubasyaroh. "Film Sebagai Media Dakwah (Sebuah Tawaran Alternatif Media Dakwah Kontemporer)." At-Tabsyir Vol. 2, no. 2 (2014): 12-13.

Musyafak, M. Ali. "Film Religi Sebagai Media Dakwah Islam." Jurnal Islamic Review Vol. II, no.2 (2013): 335-336.

Putri, Ananda. "Gairah di Industri Perfilman Nasional." SWA 2018, 27.

Republika.co.id. "Inilah Wajah Islam dalam Survei di Dunia Barat." republika.co.id, Januari 9. 2019 http://n.republika.co.id/berita/dunia-Islam/Islammancanegara/10/07/09/123929-inilah-wajah-Islam-dalam-survei-di-dunia-barat. . "Mau Baca Ayat-Ayat Cinta 2, Lihat Dulu Sinopsisnya." republika.co.id, Februari 4, 2019. http://m.republika.co.id/berita/senggang/film/15/11/24/nybiwu313-mau-bacaayatayat-cinta-2-lihat-dulu-sinopsisnya.

Sobur, Alex. Analisis Teks Media: Suatu Pengantar untuk Analisis Wacana, Analisis Semiotik, dan Analisis Framing. Bandung: Remaja Rosdakarya, 2009.

Sugiyono. Metode Penelitian Kuantitatif Kualitatif dan R\&D. Bandung: Alfabeta, 2012 Syambudi, Irwan. "Perumahan Khusus Muslim dan Ancaman Toleransi di Yogyakarta". Tirto.id, Mei 2, 2019. http://www.tirto.id/perumahan-khusus-muslim-danancaman-toleransi-di-yogyakarta-dl1D.

Wahyuda, Muhammad. "Peran film Ayat Ayat Cinta 2 Terhadap Perilaku Etika Islam Pada Remaja," Syifa Al-Qulub Vol. 2, no. 2 (2018): 31. 